\title{
AVAILABILITY OF NITROGEN, PHOSPHORUS AND POTASSIUM FROM POULTRY LITTER AND CONVENTIONAL FERTILIZERS IN A VOLCANIC SOIL CULTIVATED WITH SILAGE CORN
}

\author{
Juan Hirzel ${ }^{1 *}$, and Ingrid Walter ${ }^{2}$
}

\begin{abstract}
A B S T R A C T
Poultry litter (PL) is an organic matter source used as soil amendment. Besides its important nutrient content, it is a cheap alternative to conventional fertilizers in crop production. The efficient use of PL also helps reduce the environmental problems normally associated with its disposal near poultry production farms. This article reports the relative effects of PL and conventional fertilizers on the availability of soil N, P and K, dry matter (DM) production and total nutrient content in silage corn (Zea mays L.). The field experiment was carried out in a soil derived from volcanic ash (Tipic Melanoxerands) of Central South Chile. Corn was grown for three seasons (2002-2005) and PL and conventional fertilizers were applied in the first two years. The residual effect of the added fertilizer sources was evaluated in the third year. DM production in the fertilized treatments was similar and fluctuated between 30.6 and $37.1 \mathrm{Mg} \mathrm{ha}^{-1}$ for the two years of fertilization, and between 18.9 and $20.4 \mathrm{Mg} \mathrm{ha}^{-1}$ for the year without addition of nutrients. The plant nutrient concentrations were similar between fertilized treatments, except for the second year, in which $\mathrm{N}$ and $\mathrm{P}$ concentrations were higher with PL. During the third year (without fertilization), N decreased in the whole plant. Soil nutrient availability was similar between fertilization sources for the three years evaluated, the higher concentration being presented in the first two years (with fertilization). These results suggest that PL is an alternative fertilizer source to conventional fertilizers.
\end{abstract}

Key words: poultry litter, soil fertility, corn, nitrogen, phosphorus, potassium.

\section{INTRODUCTION}

The poultry industry in Chile has grown at a rate of $2.9 \%$ per year in the last decade. Some 193.4 million birds were produced in 2004, with a meat production of $535002 \mathrm{t}$ (INE, 2004); it is estimated that 218542 to $290100 \mathrm{t}$ of poultry litter (PL) is produced per year, considering the generation of 1.13 to $1.5 \mathrm{~kg}$ birds $^{-1} \mathrm{yr}^{-1}$ (Gascho et al., 2001). Currently the growth rate of poultry litter is nearly $15 \%$ a year (Poultry Producing Association, unpublished information). PL requires careful management and disposal since it can adversely affect the environment through gas emissions, runoff, and nutrient leaching (Sharpe et al., 2004; Mitchell and Tu, 2006; Tewolde et al., 2007), as well as threatening human health and wildlife due to pathogens (Preusch et al., 2002; Sharpe et al., 2004). A safe and environmentally friendly way of disposing of PL is to use it as a source of nutrients in agricultural production. $\mathrm{PL}$ is approximately equivalent to a 3-3-2 grade $\left(\mathrm{N}-\mathrm{P}_{2} \mathrm{O}_{5}-\mathrm{K}_{2} \mathrm{O}\right)$ fertilizer (Mitchell and $\mathrm{Tu}, 2006$ ) and has been used for the production of corn and cotton (Gossypium hirsutum L.) (Hirzel et al., 2004; Tewolde et al., 2007; Hirzel et al., 2007).

Addition of PL to cultivated land helps recycle nutrients and reduce fertilizer costs in crop production systems. Moreover, the soil nutrient availability derived from PL application is not well known. In addition, application of PL or others organic wastes may also generate a positive residual effect that should be taken into account when planning the next crop (Eghball et al., 2004; Hirzel et al., 2007). The residual $\mathrm{N}$ effect obtained with organic residues is mainly because some $\mathrm{N}$ is adsorbed or incorporated into the clay and organic soil fraction (Jensen et al., 2000) and is immobilized by soil microbial biomass (Jensen et al., 2000; Sainz et al., 2004). Sørensen and Amato (2002) found that the

\footnotetext{
${ }^{1}$ Instituto de Investigaciones Agropecuarias, Centro Regional de Investigación Quilamapu, Av. Vicente Méndez 515, Chillán, Chile. E-mail: jhirzel@inia.cl_*Corresponding author.

${ }^{2}$ Instituto Nacional de Investigación y Tecnología Agraria y Alimentaria (INIA), Apdo. Correos 8111, 28080, Madrid, España. Received: 21 September 2007. Accepted: 1 November 2007.
} 
residual $\mathrm{N}$ effect associated with the application of pig slurry to a barley (Hordeum vulgare L.) and ryegrass (Lolium perenne L.) crop rotation were about 2 to $4 \%$ and 1 to $3 \%$ of the $\mathrm{N}$ applied as manure in the second and third year, respectively.

The aim of the present study was to determine soil availability of N, P and K derived from PL and conventional fertilizer applications, and its relation to corn dry matter yield and total nutrient concentration in corn during three years of study.

\section{MATERIALS AND METHODS}

This experiment was conducted at the Santa Rosa Experimental Farm, of the Agricultural Research Institute, Regional Centre Quilamapu, Chillán (36³6' S, $\left.71^{\circ} 54^{\prime} \mathrm{W}\right)$, Chile. The soil at the site was a silty loam $0.6 \mathrm{~m}$ deep, Arrayán series, corresponding to a Typic Melanoxerands (USDA, 1994). The climate of the area is Mediterranean, with lower temperatures and high rainfall during winter and high temperatures and low rainfall in summer, which under irrigation conditions contributes to increased $\mathrm{N}$ availability for corn crops. The field trial area had been cultivated with spring wheat and oat (Avena sativa L.) in the previous four years. The initial physical and chemical properties of the soil and the chemical composition of PL (samples collected over the experimental period) are shown in Table 1.

During 2002-2004, silage corn was cultivated in a field trial established in a randomized complete block design with three treatments and four replicates. The experimental plots measured $5 \times 3.5 \mathrm{~m}$, which allowed five rows of corn spaced at $0.70 \mathrm{~m}$. The plots were orientated from East to West, and the soil had $5 \%$ of slope.

Three treatments were applied (Table 2) in 2002 and 2003. Treatment 1 (T1) was the control without fertilizer; Treatment 2 (T2) involved application of urea, triple super phosphate and potassium chloride at a rate of 400 , 300 , and $280 \mathrm{~kg} \mathrm{ha}^{-1}$ of $\mathrm{N}, \mathrm{P}_{2} \mathrm{O}_{5}$, and $\mathrm{K}_{2} \mathrm{O}$, respectively, which were adjusted to the nutrient content of Treatment

Table 1. Initial physical and chemical properties of the soil and characteristic of the poultry litter (PL) data in dry matter used in the experiment. Chillán, Chile. 2002.

\begin{tabular}{|c|c|c|c|c|}
\hline \multirow[t]{2}{*}{ Property } & \multicolumn{3}{|c|}{ Soil depth (cm) } & \multirow{2}{*}{$\begin{array}{c}\text { Poultry litter } \\
\text { Value } \pm \sigma\end{array}$} \\
\hline & $0-20$ & $20-40$ & $40-60$ & \\
\hline Bulk density, $\mathrm{g} \mathrm{cm}^{-3}$ & 1.20 & 1.25 & 1.3 & - \\
\hline Total porosity, \% & 54.72 & 52.83 & 50.94 & - \\
\hline Water retention to 0.33 bars, $\%$ & 30.02 & 25.42 & 20.04 & - \\
\hline Water retention to 15 bars, $\%$ & 15.17 & 13.44 & 12.15 & - \\
\hline Dry matter, $\mathrm{g} \mathrm{kg}^{-1}$ & & & & $700 \pm 119$ \\
\hline pH & 6.5 & 6.5 & 6.7 & $8.05 \pm 1.1$ \\
\hline $\mathrm{EC}, \mathrm{dS} \mathrm{m}^{-1}$ & - & - & - & $7.36 \pm 3.2$ \\
\hline Organic matter, \% & 6.1 & 6.4 & 2.6 & $58.10 \pm 1.25$ \\
\hline Total N, $\mathrm{g} \mathrm{kg}^{-1}$ & - & - & - & $28.57 \pm 3.5$ \\
\hline $\mathrm{C}: \mathrm{N}$ ratio & - & - & - & $11.8 \pm 1.3$ \\
\hline Inorganic $\mathrm{N}, \mathrm{mg} \mathrm{kg}^{-1}$ & 15.0 & 14.0 & 5.0 & $28.57 \pm 8.87$ \\
\hline P Olsen, $\mathrm{mg} \mathrm{kg}^{-1}$ & 11.0 & 11.0 & 6.0 & - \\
\hline Total P, $\mathrm{g} \mathrm{kg}^{-1}$ & - & - & - & $9.73 \pm 7.2$ \\
\hline Exchangeable $\mathrm{K}, \mathrm{cmol}_{\mathrm{kg}} \mathrm{k}^{-1}$ & 0.22 & 0.25 & 0.12 & - \\
\hline Total $\mathrm{K}, \mathrm{g} \mathrm{kg}^{-1}$ & - & - & - & $17.14 \pm 12.5$ \\
\hline Exchangeable $\mathrm{Ca}, \mathrm{cmol} \mathrm{kg}^{-1}$ & 5.81 & 5.31 & 2.12 & - \\
\hline Total Ca, $\mathrm{g} \mathrm{kg}^{-1}$ & - & - & - & $16.07 \pm 8.95$ \\
\hline Exchangeable $\mathrm{Mg}, \mathrm{cmol} \mathrm{kg}^{-1}$ & 0.44 & 0.42 & 0.32 & \\
\hline Total $\mathrm{Mg}, \mathrm{g} \mathrm{kg}^{-1}$ & - & - & - & $4.79 \pm 1.6$ \\
\hline Exchangeable $\mathrm{Na}, \mathrm{cmol} \mathrm{kg}^{-1}$ & 0.06 & 0.04 & 0.11 & - \\
\hline Total Na, $\mathrm{g} \mathrm{kg}^{-1}$ & - & - & - & $2.60 \pm 0.7$ \\
\hline Available $\mathrm{S}, \mathrm{mg} \mathrm{kg}^{-1}$ & 12.75 & 13.17 & 23.61 & \\
\hline Total $\mathrm{S}, \mathrm{g} \mathrm{kg}^{-1}$ & - & - & - & $3.00 \pm 1.0$ \\
\hline
\end{tabular}


3 ; and Treatment 3, which was PL used at a rate of 20 $\mathrm{Mg} \mathrm{PL} \mathrm{ha}{ }^{-1}$. In Treatment 2, urea was applied by hand, $50 \%$ one day before sowing and $50 \%$ at the six-leaf stage (between 44 to $48 \mathrm{~d}$ after sowing each year). Phosphorous and potassium fertilizers were applied once, one day before sowing. PL was broadcasted by hand one day before sowing. PL was obtained at a poultry farm near the experimental area and the litter bed material was wood shaving. No fertilizer was applied in 2004. All plots were managed to optimize crop growth according to standard management for corn silage in central Chile (Table 3)

The trial site was ploughed in early spring each year before fertilizer application. The soil was prepared with conventional tilling equipment to obtain an acceptable seedbed. Seeds were sown at a rate of 99000 to 110000 plants $\mathrm{ha}^{-1}$ according to the variety used, disinfected with chlorpirifos in dosage of $0.75 \mathrm{~g}^{100 \mathrm{~kg}^{-1} \text { seed. Weeds }}$ were controlled before sowing with two herbicides (atrazine and acetochlor in dosages of $2 \mathrm{~L} \mathrm{ha}^{-1}$ ) and later were hand controlled. Since early spring rainfall distribution differed between the two years, varieties of different precocity were used (data not showed).

Table 2. Nutrients applied in the different treatments in the first two seasons (2002 and 2003).

\begin{tabular}{|c|c|c|c|c|}
\hline \multirow[t]{2}{*}{ Treatment } & \multirow[t]{2}{*}{ Year } & \multicolumn{3}{|c|}{ Nutrient rate } \\
\hline & & $\mathbf{N}$ & $\mathrm{P}_{2} \mathrm{O}_{5}$ & $\mathrm{~K}_{2} \mathrm{O}$ \\
\hline & & & $\mathrm{kg}$ ha- & \\
\hline \multirow[t]{2}{*}{$\mathrm{T} 1$} & 2002 & 0 & 0 & 0 \\
\hline & 2003 & 0 & 0 & 0 \\
\hline \multirow[t]{2}{*}{$\mathrm{T} 2$} & 2002 & 400 & 300 & 280 \\
\hline & 2003 & 400 & 300 & 280 \\
\hline \multirow[t]{2}{*}{$\mathrm{T} 3$} & 2002 & 400 & 300 & 280 \\
\hline & 2003 & 400 & 300 & 280 \\
\hline
\end{tabular}

$\mathrm{T} 1$ : control; $\mathrm{T} 2$ : high rate conventional fertilizer; $\mathrm{T} 3$ : high rate poultry litter.
At sowing, five polyvinyl chloride (PVC) tubes $20 \mathrm{~cm}$ long and $5 \mathrm{~cm}$ wide were completely inserted in the center of each treatment plot, between seeded rows (Raison et al., 1987; Eghball, 2000; He et al., 2000). The PVC tubes were collected each $30 \mathrm{~d}$ after seeding (Eghball, 2000). The soil was mixed thoroughly in a bucket, air-dried and sieved through a $2 \mathrm{~mm}$ mesh before analysis. Soil $\mathrm{pH}$ was measured in water (1:2.5 soil/water ratio) (Sadzawka et al., 2006). Available soil $\mathrm{P}$ was determined by extracting $2.5 \mathrm{~g}$ of soil with $50 \mathrm{~mL}$ of $0.5 \mathrm{M} \mathrm{NaHCO}_{3}$ for $30 \mathrm{~min}$, according to the method of Olsen et al. (1954). Available K was determined using $1 \mathrm{M} \mathrm{NH}_{4} \mathrm{OAc}$ extraction followed by atomic absorption-emission spectrophotometer, as described by Sadzawka et al. (2006). Inorganic $\mathrm{N}$ $\left(\mathrm{NO}_{3}-\mathrm{N}+\mathrm{NH}_{4}-\mathrm{N}\right)$ was extracted using $2 \mathrm{M} \mathrm{KCl}$ and determined colorimetrically using a segmented flow autoanalyzer spectrophotometer (Skalar, Sanplus, Breda, The Netherlands).

Corn was harvested at silage maturity (30-35\% DM) (Plénet and Lemaire, 2000; Millner et al., 2005). Ten contiguous plants in the central row were cut $10 \mathrm{~cm}$ above soil surface, weighed in situ with a portable balance and ground with a mechanical shredder (Craftsman, USA).

Plant $\mathrm{N}$ was determined by the macro-Kjeldahl procedure (Sadzawka et al., 2001). The $\mathrm{P}$ and $\mathrm{K}$ concentrations were determined by ashing $2 \mathrm{~g}$ sub-sample in a ceramic crucible at $500^{\circ} \mathrm{C}$ for $7 \mathrm{~h}$, dissolving the ash in $10 \mathrm{~mL}$ of boiling $2 \mathrm{M} \mathrm{HCl}$ for 5-10 min, and filtering through Whatman No.5 paper (Sadzawka et al., 2001). The $\mathrm{P}$ and $\mathrm{K}$ concentrations were measured in the extract by colorimetric method and by atomic emission spectroscopy (Sadzawka et al., 2001).

Table 3. Crop management information in the three seasons.

\begin{tabular}{lccc}
\hline & $\mathbf{2 0 0 2 - 2 0 0 3}$ & $\mathbf{2 0 0 3 - 2 0 0 4}$ & $\mathbf{2 0 0 4 - 2 0 0 5}$ \\
\hline Corn variety & DK567 (Dekalb) & P3527 (Pioneer) & TX75 (Tracy) \\
Plant population ha ${ }^{-1}$ & 102041 & 102041 & 102041 \\
Sowing date & 10 November & 16 October & 29 October \\
Harvest date & 25 March & 25 February & 18 March \\
Days from sowing to harvest & 135 & 132 & 140 \\
PL application date & 9 November & 15 October & - \\
Conventional fertilizer & 9 November & 15 October & - \\
Application date & 6 January & 14 December & \\
\hline
\end{tabular}

PL: poultry litter. 
Collected data were analyzed by ANOVA and the least significant difference (LSD) test $(P=0.05)$ was applied to determine statistical differences between nutrient treatments using the SAS software general model procedure (SAS Institute, 1989).

\section{RESULTS AND DISCUSSION}

\section{Crop dry matter production}

The highest DM production was obtained during the first two years, those with fertilizer applications, and DM fluctuated between 30.6 and $37.1 \mathrm{Mg} \mathrm{ha}^{-1}$ (Figure 1), similar to the values reported by Hirzel et al. (2004). During this period, DM of fertilized treatments was significantly higher than that of the control treatment. The differences observed between control and fertilized treatments were smaller in the second year, which could be due to the different variety of corn sown in the second year (Heckman et al., 2003) and to the shorter vegetative period of the crop (Table 3 ).

In the third year, average DM production in the fertilized treatments decreased by $13.6 \mathrm{Mg} \mathrm{ha}^{-1}$, from 33.3 to 19.7 $\mathrm{Mg} \mathrm{ha}^{-1}$ (Figure 1). At the same time, DM production in the control treatment decreased by $5.6 \mathrm{Mg} \mathrm{ha}^{-1}$, from 20.5 to $14.9 \mathrm{Mg} \mathrm{ha}^{-1}$, indicating a limited nutrient supply associated with a lack of fertilization that year and/or a low turnover of soil organic matter. There was no residual effect from the application of fertilizer sources on DM production (Figure 1).

\section{Availability of soil nitrogen, phosphorus and potassium}

Nutrient availability was studied in the first $20 \mathrm{~cm}$ of soil, because the greatest changes in concentrations due to changes in fertilization are produced at this depth (Eghball, 2000). Nutrient concentration at deeper layers was similar between evaluated treatments (Hirzel, 2007).

\section{Nitrogen}

Similar dynamics in available $\mathrm{N}$ were observed in fertilized treatments during the growing seasons of the first two years (Figure 2). The first year there was higher $\mathrm{N}$ availability during the first two months in treatments with fertilization. At the same time, there were some differences between treatments with fertilization, indicating higher $\mathrm{N}$ availability in the first month with the conventional fertilization. In contrast, in the second month higher $\mathrm{N}$ availability was obtained with PL. These result partly coincide with those published by Dean et al. (2000) and differ from those reported by $\mathrm{He}$ et al. (2000). In this experiment, higher soil $\mathrm{N}$ concentration was found in the first two months, which differs from the longer period of availability indicated by Dean et al. (2000) for a raspberry (Rubus idaeus L.)

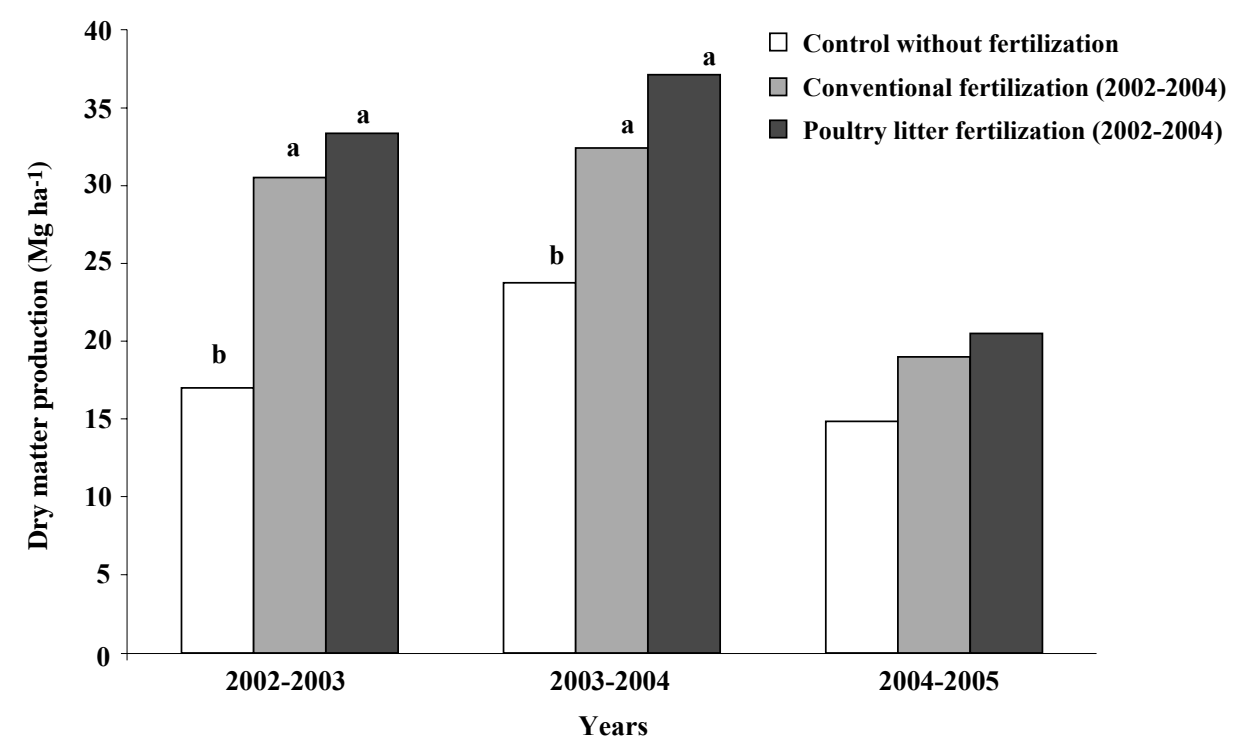

Figure 1. Mean dry matter yields in the whole plant for the three growing seasons. T1: control; T2: high rate conventional fertilizer; T3: high rate poultry litter.

Bars with different letters in the same year indicate significant differences according to LSD test $(\mathrm{P}<0.05)$.

There are not statistical differences in the third season. 
crop fertilized with PL. The initial high $\mathrm{N}$ availability may be associated with a high concentration of uric acids in PL (Gordillo and Cabrera, 1997). In the first year, the available $\mathrm{N}$ fraction in the PL treatment, in comparison to the control, was 12 and $30 \%$ of the total $\mathrm{N}$ applied, for the first and second month of evaluation, respectively (Figure 2a). In contrast for the same year, the available $\mathrm{N}$ fraction was 30 and $40 \%$ of the $\mathrm{N}$ added as urea during the first and second month, respectively. The lower $\mathrm{N}$ availability obtained initially with PL may be associated with greater $\mathrm{N}$ immobilization by the active soil microbial biomass growing in the soluble carbon added to the soil through PL (Ma et al., 1999).

In the second season, there was a higher availability of $\mathrm{N}$ in the first two months (Figure 2b). Moreover, $\mathrm{N}$ concentrations during the first three months of evaluation were higher in the second year, and fluctuated between 50 and $130 \mathrm{mg} \mathrm{kg}^{-1}$ in the urea and PL treatments with fertilization, which is similar to what was indicated by Eghball (2000). The available $\mathrm{N}$ fraction for the PL treatment was 18 and $20 \%$ higher compared to the control for the first and second month of the second year, respectively. For the conventional fertilization treatment, this fraction was 18 and $42 \%$ compared to the control for the first and second month of evaluation, respectively. Comparatively, organic $\mathrm{N}$ mineralization in the PL treatment was more controlled over time than conventional fertilization, which is an additional advantage to using it as fertilization source, because it allows for decreasing the risk of $\mathrm{N}^{-\mathrm{NO}_{3}}$ lixiviation. In the PL treatment, $\mathrm{N}$ availability for the first month of evaluation was statistically similar to the mineral fertilization, compared to first evaluation year, suggesting that in the second year there was a residual $\mathrm{N}$ supply, which could come from the stable $\mathrm{N}$ fraction in the PL applied in the first year.

In the third year, the evolution of available soil $\mathrm{N}$ was similar between the treatments (Figure 2c), with higher $\mathrm{N}$ availability in the first two months. In general, $\mathrm{N}$ concentration in the third year was lower than in the first two years of evaluation, because no fertilization was applied the last year. These results are similar to those indicated by Cooperband et al. (2002) and Binder et al. (2002).

\section{Phosphorus}

During the first two years of evaluation with fertilization a similar behavior was observed between treatments with fertilization (T2 and T3), presenting a higher concentration than the control (Figure 3). (a)

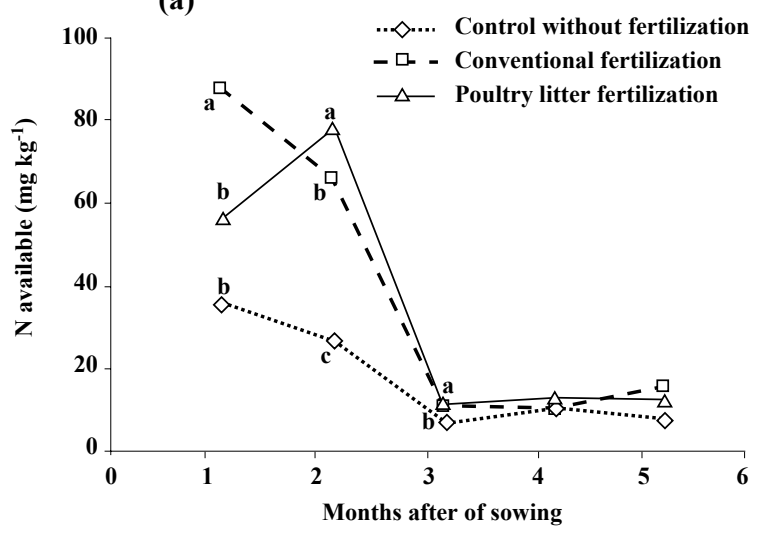

(b)

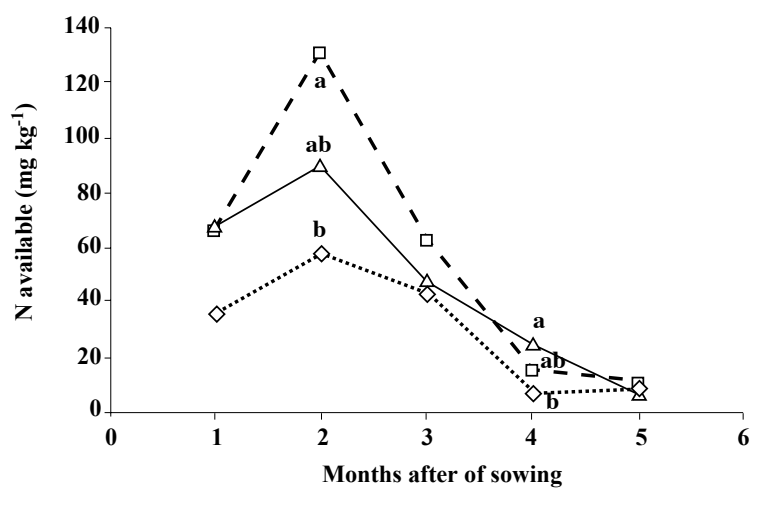

(c)

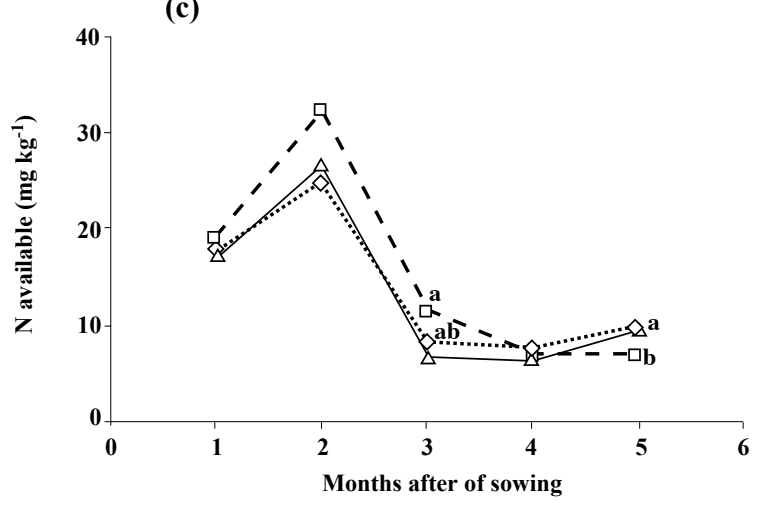

Figure 2. Available soil nitrogen in the 0-20 $\mathrm{cm}$ depth in the growing seasons of silage corn. (a) 2002-2003; (b) 2003-2004; (c) 2004-2005.

Different letters for the same sampling date indicate statistical differences according to LSD test $(\mathrm{P}<0.05)$. 
In the first year, $\mathrm{P}$ concentration fluctuated between 15 and $20 \mathrm{mg} \mathrm{kg}^{-1}$ in the treatments with fertilization (Figure $3 \mathrm{a}$ ). The average relative $P$ availability compared to the control was 28.9 and $32.4 \%$ higher in the PL and conventional fertilization, respectively, for all the evaluation period. This results were lower that those indicated by Eghball and Power (1999) and Mitchell and $\mathrm{Tu}$ (2006). Available $\mathrm{P}$ at the end of the incubation period in the fertilized treatments was slightly higher than in the control without fertilization, in contrast to what was indicated by Cooperband et al. (2002) for a similar investigation in a silty loam soil. This effect responds to the high $\mathrm{P}$ fixation capacity of the soil used (Beck et al., 1998; Barreal et al., 2001; Haynes and Mokolobate, 2001; Staats et al., 2004).

In the second year, $\mathrm{P}$ concentration fluctuated between 18 and $29 \mathrm{mg} \mathrm{kg}^{-1}$ in treatments with fertilization (Figure $3 b)$. Average relative $P$ availability, in comparison to the control, was 40.7 and $42.3 \%$ higher in the PL and conventional fertilization, respectively, for all the evaluation period. In general, relative $P$ availability in the second year was slightly higher than in the first year.

In the third year (without fertilization), P concentration was lower than in the previous years (with fertilization) and fluctuated between 14 and $20 \mathrm{mg} \mathrm{kg}^{-1}$ in fertilized treatments (Figure 3c). Moreover, P concentration in the control was similar to the other treatments, suggesting that there was no residual effect of $P$ fertilization, which responds to the high soil P fixation capacity (Barreal et al., 2001; Beck et al., 1998; Haynes and Mokolobate, 2001; Staats et al., 2004).

\section{Potassium}

During the first two years, a similar behavior was observed between fertilized treatments (T2 and T3) (Figure 4). In the first year there was a higher $\mathrm{K}$ availability in treatments with fertilization during the first two months of evaluation, but only the conventional fertilization application generated a $\mathrm{K}$ concentration statistically higher than the control (Figure 4a). In the fourth and fifth months of evaluation there was no difference between treatments, which could reflect a movement of $\mathrm{K}$ from the surface horizon to a deeper horizon, as was indicated by Morton et al. (2004) for allophanic soils in New Zealand. K concentration fluctuated between 82 and $240 \mathrm{mg} \mathrm{kg}^{-1}$ in the treatments with fertilization. Average relative $\mathrm{K}$ availability for the conventional fertilization and PL treatment was higher by 50.5 and $43.7 \%$, respectively, compared to the control. These (a)

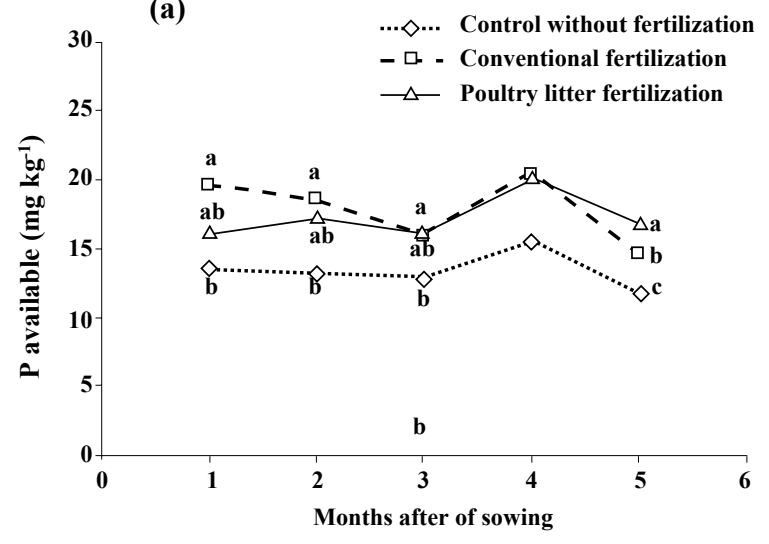

(b)

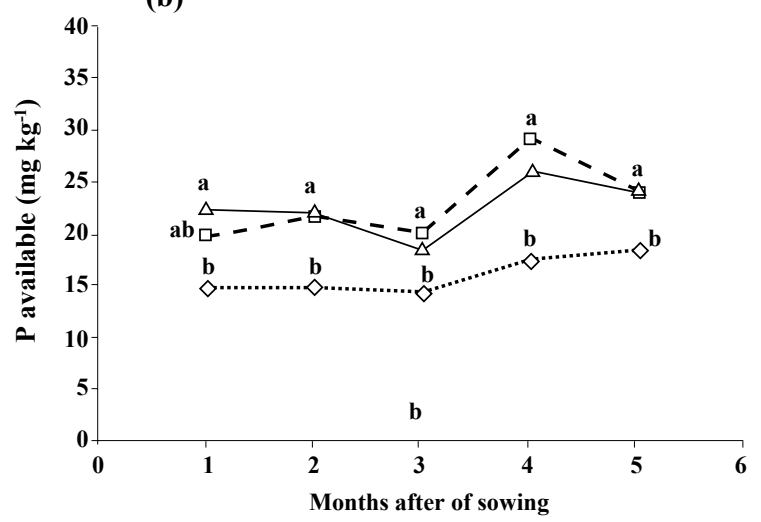

(c)

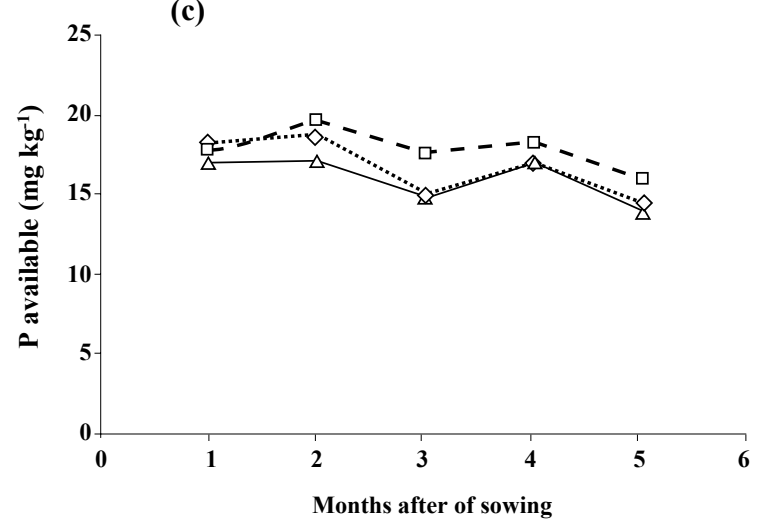

Figure 3. Available soil phosphorus in the $0-20 \mathrm{~cm}$ depth over the growing seasons of silage corn. (a) 2002-2003; (b) 2003-2004; (c) 2004-2005.

Different letters for the same sampling date indicate statistical differences according to LSD test $(\mathrm{P}<0.05)$. 
values were lower than those reported by Mitchell and $\mathrm{Tu}$ (2006) in a similar experiment in a silty loam soil with cotton.

In the second year, the highest $\mathrm{K}$ availability was obtained in the PL treatment for the whole period of evaluation, and was statistically higher than that of the control (Figure $4 \mathrm{~b}$ ). In general and similar to first year, a higher $\mathrm{K}$ availability was observed during the first months after application of fertilization treatments, with decreasing content over time, probably due to $\mathrm{K}$ movement in depth, an effect previously discussed. K concentration in treatments with fertilization fluctuated between 179 and $308 \mathrm{mg} \mathrm{kg}^{-1}$, higher than in the first year (Figure 4a). Average relative K availability, in comparison to the control, was higher by 37.3 and $59.9 \%$ for the conventional fertilization and PL treatment, respectively. In contrast to the results obtained in the first year, higher relative $\mathrm{K}$ availability in the PL treatment was observed.

In the third year, $\mathrm{K}$ concentration was generally lower than in the first two years (with fertilization) and there were no statistical differences between treatments (Figure 4c).

\section{Nutrient concentration in the whole plant}

A higher $\mathrm{N}$ concentration was obtained in fertilized treatments the first year, the same as was indicated by Eghball et al. (2004) and Chantigny et al. (2004), and fluctuated between 9.78 and $9.85 \mathrm{~g} \mathrm{~kg}^{-1}$ (Table 4), which was consistent with results obtained in soil (Figure 2a). In general, $P$ concentration was not different between the treatments, which coincides with some authors (Mazzarino et al., 1997; Cuevas and Walter, 2004) and fluctuated between 1.79 and $2.23 \mathrm{~g} \mathrm{~kg}^{-1}$ for fertilized treatments. This effect did not coincide with soil available P (Figure 3a and 3b) and could be due to the higher DM production obtained in the fertilized treatments, which generated a dilution of $\mathrm{P}$ uptake and successively a P concentration similar to control. At the same time, the plants presence stimulates an increment in the activity of enzymes specifically for P present in organic compounds (Ibrickci et al., 1994), which could explain the $\mathrm{P}$ concentration obtained in the control. The $\mathrm{K}$ contents presented higher values in the fertilized treatments, and fluctuated between 9.65 and $10.98 \mathrm{~g} \mathrm{~kg}^{-1}$.

$\mathrm{N}$ concentration was lower the second year (Table 4), probably because a different corn variety was used (Heckman et al., 2003). Highest $\mathrm{N}$ concentration in
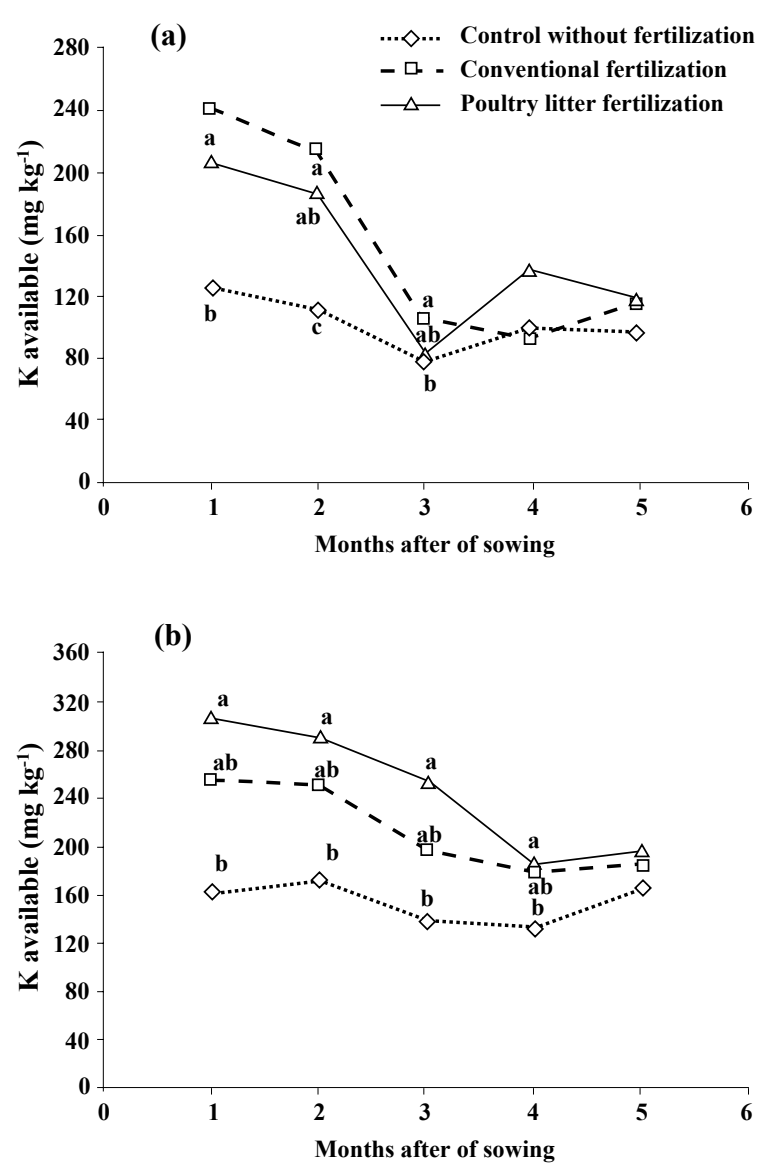

(c)

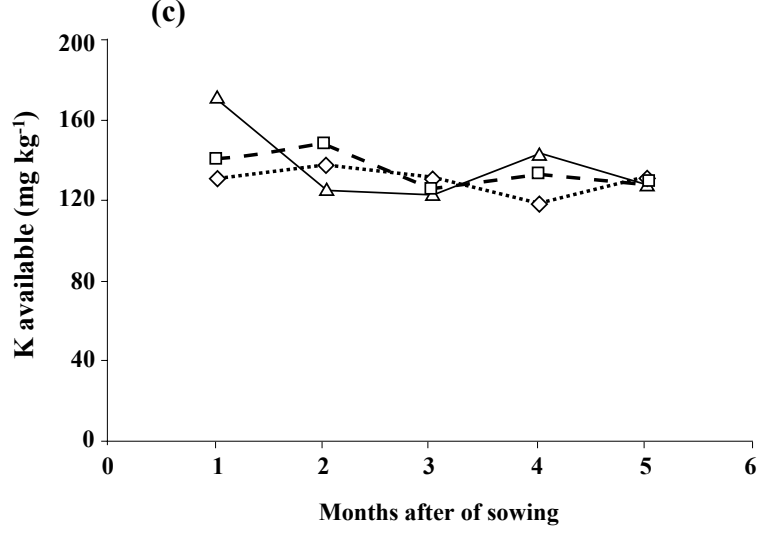

Figure 4. Available soil potassium in the $0-20 \mathrm{~cm}$ depth over the growing seasons of silage corn. (a) 20022003; (b) 2003-2004; (c) 2004-2005.

Different letters for the same sampling date indicate statistical differences according to LSD test $(\mathrm{P}<0.05)$. 
plant and DM production in PL treatment could have generated a dilution of soil $\mathrm{N}$ concentration. This effect can decrease the differences in soil $\mathrm{N}$ concentration between treatments (Figure 2b). At the same time, the highest $\mathrm{P}$ concentration was obtained in the PL treatment. Moreover, this effect was not observed in the soil (Figure $3 b$ ). For $\mathrm{K}$ concentration there were no differences between treatments, probably associated with higher DM production in treatments with fertilization that generated a dilution of $\mathrm{K}$ in the plant.

There were no differences in the third year in nutrient concentrations between treatments, which coincides with the low residual effect observed in soil (Figures $2 \mathrm{c}, 3 \mathrm{c}$ and $4 \mathrm{c})$.

Table 4. Nutrient concentration $\left(\mathrm{g} \mathrm{kg}^{-1}\right)$ in the whole plant during the evaluation period.

\begin{tabular}{clrrr}
\hline Nutrient & Season & T1 & T2 & T3 \\
\hline $\mathrm{N}$ & First & $7.63 \mathrm{~b}$ & $9.78 \mathrm{a}$ & $9.85 \mathrm{a}$ \\
& Second & $5.65 \mathrm{~b}$ & $6.70 \mathrm{~b}$ & $8.38 \mathrm{a}$ \\
& Third & $5.43 \mathrm{a}$ & $5.58 \mathrm{a}$ & $5.53 \mathrm{a}$ \\
$\mathrm{P}$ & First & $1.75 \mathrm{a}$ & $1.79 \mathrm{a}$ & $2.23 \mathrm{a}$ \\
& Second & $1.33 \mathrm{~b}$ & $1.43 \mathrm{~b}$ & $1.58 \mathrm{a}$ \\
& Third & $1.80 \mathrm{a}$ & $1.40 \mathrm{a}$ & $1.50 \mathrm{a}$ \\
$\mathrm{K}$ & First & $7.43 \mathrm{~b}$ & $10.98 \mathrm{a}$ & $9.65 \mathrm{a}$ \\
& Second & $7.75 \mathrm{~b}$ & $8.85 \mathrm{a}$ & $8.98 \mathrm{a}$ \\
& Third & $7.60 \mathrm{a}$ & $8.43 \mathrm{a}$ & $8.90 \mathrm{a}$ \\
\hline
\end{tabular}

T1: control; T2: high rate of conventional fertilization; T3: high rate of poultry litter.

Values with different letters in the same line indicate significant differences according to LSD test $(\mathrm{P}<0.05)$.

\section{CONCLUSIONS}

The results obtained indicated that PL used as a fertilization source in corn crops generates similar levels of nutrient availability in the soil, DM production, and total nutrient concentrations in plant, without affecting residual concentrations of soil nutrients, so it is an alternative to conventional fertilizers as a nutritional source for crops.

\section{R E S U M E N}

Disponibilidad de nitrógeno, fósforo y potasio de cama de broiler y fertilizantes convencionales en un suelo volcánico cultivado con maíz. Juan Hirzel $^{1 *}$, e Ingrid Walter ${ }^{2}$. La cama de broiler (PL) es un compuesto orgánico utilizado como enmienda de suelos, cuyo contenido de nutrientes y bajo precio permiten considerarla como una alternativa al uso de fertilizantes. El uso de PL como fertilizante permite disminuir el riesgo de contaminación ambiental en las zonas de acopio. En este trabajo se compara el efecto en producción de materia seca (DM), y concentración de nutrientes en maíz (Zea mays L.) para ensilaje, y disponibilidad de N, P y K en un suelo volcánico (Tipic Melanoxerands) de la zona centro sur de Chile, obtenido con PL, fertilizantes convencionales y un control sin fertilización. El cultivo fue realizado durante tres temporadas consecutivas; en las dos primeras se fertilizó y la tercera temporada permitió conocer el efecto residual de la fertilización aplicada. La producción de DM fue similar entre los tratamientos con fertilización, y fluctuó entre 30,6 y 37,1 Mg ha-1 para los años con fertilización, y entre 18,9 y 20,4 $\mathrm{Mg} \mathrm{ha}^{-1}$ para el año posterior (sin fertilización). La concentración de nutrientes fue similar entre tratamientos fertilizados, excepto para el segundo año, en el cual el $\mathrm{N}$ y $\mathrm{P}$ fueron mayores con PL. El tercer año, la ausencia de fertilización redujo la concentración de $\mathrm{N}$ en los tejidos. En el suelo, la disponibilidad de nutrientes fue similar con ambas fuentes de fertilización, aunque las mayores concentraciones se obtuvieron durante los años en que se aplicaron fertilizantes. Los resultados obtenidos sugieren que PL es una fuente de fertilización alternativa al uso de fertilizantes convencionales.

Palabras clave: cama de broiler, fertilidad de suelos, maíz, nitrógeno, fósforo, potasio. 


\section{LITERATURE CITED}

Barreal, M.E., M. C. Arbestain, F. Macías, and A.E. Fertitta. 2001. Phosphate and sulfate retention by nonvolcanic soils with andic properties. Soil Sci. 166:691-707.

Beck, M., W. Robarge, and S. Buol. 1998. Phosphorus retention and release of anion and organic carbon by two Andisols. Eur. J. Soil Sci. 50:157-164.

Binder, D.L., A. Dobermann, D.H. Sander, and K.G. Cassman. 2002. Biosolids as nitrogen source for irrigated maize and rainfed sorghum. Soil Sci. Soc. Am. J. 66:531-543.

Chantigny, M.H., D.A. Angers, T. Morvan, and C. Pomar. 2004. Dynamics of pig slurry nitrogen in soil and plant as determined with $15 \mathrm{~N}$. Soil Sci. Soc. Am. J. 68:637-643.

Cooperband, L., G. Bollero, and F. Coale. 2002. Effect of poultry litter and compost on soil nitrogen and phosphorus availability and corn production. Nutr. Cycl. Agroecosyst. 62:185-194.

Cuevas, G., e I. Walter. 2004. Metales pesados en maíz (Zea mays L.) cultivado en un suelo enmendado con diferentes dosis de compost de lodo residual. Rev. Int. Contam. Ambient. 20:59-68.

Dean, D.M., B.J. Zebarth, C.G. Kowalenko, J.W. Paul, and K. Chipperfield. 2000. Poultry manure effects on soil nitrogen processes and nitrogen accumulation in red raspberry. Can. J. Plant Sci. 80:849-860.

Eghball, B. 2000. Nitrogen mineralization from fieldapplied beef cattle feedlot manure or compost. Soil Sci. Soc. Am. J. 64:2024-2030.

Eghball, B., D. Ginting, and J.E. Gilley. 2004. Residual effects of manure and compost applications on corn production and soil properties. Agron. J. 96:442447.

Gascho, G.J., R.K. Hubbard, T.B. Brenneman, A.W. Johnson, D.R. Sumner, and G.H. Harris. 2001. Effects of broiler litter in an irrigated, double-cropped, conservationtilled rotation. Agron. J. 93:1315-1320.

Gordillo, R.M., and M.L. Cabrera. 1997. Mineralizable nitrogen in broiler litter: I. Effect of selected litter chemical characteristics. J. Environ. Qual. 26:16721679.

Haynes, R.J., and M.S. Mokolobate. 2001. Amelioration of Al toxicity and P deficiency in acid soils by additions of organic residues: a critical review of the phenomenon and the mechanisms involved. Nutr. Cycl. Agroecosyst. 59:47-63.

He, Z.L., A.K. Alva, P. Yan, Y.C. Li, D.V. Calvert, P.J. Stoffella, and D.J. Banks. 2000. Nitrogen mineralization and transformation from composts and biosolids during field incubation in a sandy soil. Soil Sci. 165:161-169.
Heckman, J.R., J.T. Sims, D.B. Beegle, F.J. Coale, S.J. Herbert, T.W. Bruulsema, and W.J. Bamka. 2003. Nutrient removal by corn grain harvest. Agron. J. 95:587-591.

Hirzel, J. 2007. Estudio comparativo entre fuentes de fertilización convencional y orgánica, cama de broiler, en el cultivo de maíz (Zea mays L.). 139 p. Tesis Doctoral. Escuela Técnica Superior de Ingenieros Agrónomos. Universidad Politécnica de Madrid. España.

Hirzel, J., N. Rodríguez, and E. Zagal. 2004. Effect of different doses of $\mathrm{N}, \mathrm{P}, \mathrm{K}$ inorganic fertilization and organic source (poultry litter) on maize production and soil fertility. Agric. Tec. (Chile) 64:365-374.

Hirzel, J., I. Walter, P. Undurraga, and M. Cartagena. 2007. Residual effects of poultry litter on silage maize (Zea mays L.) growth and soil properties derived from volcanic ash. Soil Sci. Plant Nutr. 53:480-488.

Ibrickci, H., N.B. Comerford, E.A. Hanlon, and J.E. Rechcigl. 1994. Phosphorus uptake by bahiagrass from Spodosols: Modeling of uptake from different horizons. Soil Sci. Soc. Am. J. 58:139-143.

INE. 2004. Beneficio de aves por tipo y especies. Instituto Nacional de Estadística, Santiago, Chile. [En línea]. ISO. Available at: http://www.ine.cl/ine/canales/ chile_estadístico/compendio_estadístico/pdf/2005 (Accessed 26 December 2005).

Jensen, L.S., I.S. Pedersen, T.B. Hansen, and N.E. Nielsen. 2000. Turnover and fate of ${ }^{15} \mathrm{~N}$-labelled cattle slurry ammonium-N applied in the autumn to winter wheat. Eur. J. Agron. 12:23-35.

Ma, B.L., L.M. Dwyer, and E.G. Gregorich. 1999. Soil nitrogen amendment effects on nitrogen uptake and grain yield of maize. Agron. J. 91:650-656.

Mazzarino, M.J., I. Walter, G. Costa, F. Laos, L. Roselli, and P. Satti. 1997. Plant response to fish farming wastes in volcanic soils. J. Environ. Qual. 26:522-528.

Millner, J.P., R. Villaver, and A.K. Hardacre. 2005. The yield and nutritive value of maize hybrids grown for silage. N.Z. J. Agric. Res. 48:101-108.

Mitchell, C., and S. Tu. 2006. Nutrient accumulation and movement from poultry litter. Soil Sci. Soc. Am. J. 70:2146-2153.

Morton, J.D., C.G. Roach, M.J. Tong, and A.H.C. Roberts. 2004. Potassium in soil and pasture and leaching of cations on an allophanic soil in New Zealand. N.Z. J. Agric. Res. 47:147-154.

Olsen, S.R., C.V. Cole, F.S. Watanabe, and L.A. Dean. 1954. Estimation of available phosphorus in soils by extraction with sodium bicarbonate. USDA Circ. 939:1-19. U.S. Government Printing Office, Washington D.C., USA. 
Plénet, D., and G. Lemaire. 2000. Relationships between dynamics of nitrogen uptake and dry matter accumulation in maize crops. Determination of critical $\mathrm{N}$ concentration. Plant Soil 216:65-82.

Preusch, P.L., P.R. Adler, L.J. Sikora, and T.J. Tworkosky. 2002. Nitrogen and phosphorus availability in composted and uncomposted poultry litter. J. Environ. Qual. 31:2051-2057.

Raison, R.J., M.J. Connell, and P.K. Khanna. 1987. Methodology for studying fluxes of soil mineral N in situ. Soil Biol. Biochem. 19:521-530.

Sadzawka, A., M.A. Carrasco, R. Grez, M. Mora, H. Flores, y A. Neaman. 2006. Métodos de análisis recomendados para los suelos de Chile. 164 p. Serie Actas INIA $\mathrm{N}^{\circ}$ 34. Instituto de Investigaciones Agropecuarias, Santiago, Chile.

Sadzawka, A., R. Grez, M.L. Mora, N. Saavedra, y M.A. Carrasco. 2001. Métodos de análisis de tejidos vegetales. 53 p. Comisión de Normalización y Acreditación. Sociedad Chilena de la Ciencia del Suelo, Santiago, Chile.

Sainz, H.R., H.E. Echeverría, and P.A. Barbieri. 2004. Nitrogen balance as affected by application time and nitrogen fertilizer rate in irrigated no-tillage maize. Agron. J. 96:1622-1631.
SAS Institute. 1989. Usage and reference. Version 6. 501 p. SAS Institute Inc., Cary, North Carolina, USA.

Sharpe, R.R., H.H. Schomberg, L.A. Harper, D.M. Endale, M.B. Jenkins, and A.J. Franzluebbers. 2004. Ammonia volatilization from surface-applied poultry litter under conservation tillage management practices. J. Environ. Qual. 33:1183-1188.

Sørensen, P., and M. Amato. 2002. Remineralisation and residual effects of $\mathrm{N}$ after application of pig slurry to soil. Eur. J. Agron. 16:81-95.

Staats, K.E., Y. Arai, and D.L. Sparks. 2004. Alum amendment effects on phosphorus release and distribution in poultry litter-amended sandy soils. J. Environ. Qual. 33:1904-1911.

Tewolde, H., K.R. Sistani, D.E. Rowe, and A. Adeli. 2007. Phosphorus extraction by cotton fertilized with broiler litter. Agron. J. 99:999-1008.

USDA. 1994. Key to soil taxonomy. 306 p. $6^{\text {th }}$ ed. United States Department of Agriculture (USDA), Washington, D.C., USA. 